\title{
Association between Feline Immunodeficiency Virus Antibodies and Host Characteristics in Finnish Cats
}

\author{
By A. Sukura, Y. T. Gröhn, J. Junttila, and T. Palolahti \\ Departments of Anatomy and Microbiology, College of Veterinary Medicine, Helsinki and Vetlab, Tampere, \\ Finland and Department of Clinical Sciences, New York State College of Veterinary Medicine, Cornell Uni- \\ versity, Ithaca, USA.
}

\begin{abstract}
Sukura A., Y. T. Gröhn, J. Junttila and T. Palolahti: Association between feline immunodeficiency virus antibodies and host characteristics in Finnish cats. Acta vet. scand. 1992, 33, 325-334. - Toward the end of 1989 the largest private veterinary laboratory in Finland (Vet/lab) began using a commercial combined ELISA test for Feline Immunodeficiency Virus (FIV) antibodies and Feline Leukemia Virus (FeLV) antigens $\left(\right.$ Cite $\mathrm{Combo}^{\mathrm{R}}$ ). The overall proportion of FIV seropositive feline samples was $5 \%$ during the 22 month study period. The number of tests performed increased slowly while the positive test results decreased with time $(7 \%$ in 1990 and $4 \%$ in 1991). The decrease in prevalence was assumed to reflect a change in the sample population rather than an actual change in the general cat population. There were more symptomatic and domestic cats tested in 1990 than 1991. The lower-risk groups in the second year of the study may simply be an indication that the cat owners became more aware of FIV and the motivation to send samples switched from the veterinarian's interest to diagnose the disease in a symptomatic cat to the owner's interest to survey their cats for possible FIV infection. In a multivariable analysis, breed, symptoms, age and sex were associated with the risk of FIV seropositivity. The risk increased faster with age in males than in females (i.e., the age effect was not constant between sexes). The cats with symptoms had a higher risk than those without symptoms and non-purebred cats were at a higher risk than purebred cats. FeLV infection was not associated with FIV.
\end{abstract}

retroviridae; lentivirus; ELISA; logistic regression; cat.

\section{Introduction}

Feline Immunodeficiency Virus (FIV) is the most recently described member of the feline retrovirus family. It was isolated in 1986 in Northern California from a cattery where cats were suffering from an immunodeficiency-like syndrome (Pedersen et al. 1987). Since then, much research has been devoted to FIV, partly because it was thought to be a good animal model for Human Immunodeficiency Virus (HIV) infection (North et al. 1989). Although the 2 viruses belong to the same subfamily (lentivirus) they are, like all other lentiviruses, very host specific (Connaughton 1989). Thus far, no public health risk of FIV has been reported (Pedersen et al. 1991). A retrospective study of serum bank material found antibodies to the virus as early as 1968 (Shelton et al. 1989). Antibodies have been found from every continent (Har$d y$ 1991), and it is believed that the epidemiologic pattern of the infection is more endemic than epidemic (Povey et al. 1989). The virus can be isolated from cerebrospinal fluid, blood, and saliva of infected animals 
(Yamamoto et al. 1988), and thus it is thought to be spread by saliva through bites; the virus is not very contagious in a cat population where the social order is stable (Yamamoto et al. 1988). A finding that intact males and neutered cats had the same risk of infection suggests that transmission in sexual intercourse is unlikely (Ishida et al. 1989, Hosie et al. 1989). In utero transmission has not been proven, but there is a suggestion that lactogenic transmission may occur (Callanan et al. 1991). There is also evidence that female cats may transmit antibodies passively to kittens (Callanan et al. 1991). As transmission is believed to occur primarily during cat fights, particularly among males, it seems likely that risk factors are associated with cat behavior. This assumption is supported by epidemiologic studies in which a higher prevalence was found among free roaming cats. Furthermore, males seemed to be more often infected than females. The peak prevalence of infection is reported for cats 5 to 6 years of age and older (Yamamoto et al. 1989, Ishida et al. 1989, Hosie et al. 1989). Commonly, FIV has been compared with another feline retrovirus, the Feline Leukemia Virus (FeLV). However, FeLV infects younger cats than FIV does. This is thought to reflect a long latent period for FIV, perhaps as long as 5 years (Pedersen et al. 1991).

There have been few studies on the prevalence of FIV in Nordic countries. Sukura et al. (1992) surveyed prevalence of FIV antibodies among free-roaming cats in the capital area of Finland, and Kristensen et al. (1989) conducted a study in Denmark. The objectives of the study reported here were 1 ) to investigate if anamnestic data (describing cat behavior) are associated with FIV and 2) to obtain some estimation of the prevalence of FIV infection in clinical material in Finland.

\section{Materials and methods}

Source of data

Records of all combined FeLV antigen and FIV antibody tests (Cite Combo ${ }^{\mathrm{R}}$ ) from the largest private veterinary laboratory in Finland (Vetlab, Tampere) from January 5, 1990 to November 22, 1991 formed the data base for this study. In Finland, it is common to send feline serology samples to a laboratory for analysis rather than to run the tests in a local clinic. Because every major small animal clinic in Finland is known to use this laboratory, it was likely that practically all ELISA tests for FIV antibodies during the study period were included in the data base. Samples were from 198 different clinicians from all areas of Finland; most of the samples came from the southern part of the country where the human population density is highest. Only clearly positive tests were considered as positive (all equivocal results were deleted from the data set) and if the animal was tested several times only the first record was included. The test has been reported to have $98.3 \%$ sensitivity and $100 \%$ specificity (O'Connor et al. 1991). There are also indirect indications that the specificity may be over $99 \%$ (O'Connor et al. 1991).

Available data included name of the referring veterinary clinic, name of the cat, record number, breed of the cat, date of birth, date of testing, sex and clinical symptoms. The completeness of the anamnestic information was quite variable. After editing the data 1713 cats remained in the study population. Information on symptoms was available for 189 cats ( $11 \%$ of studied animals). If there was any information on symptoms, the cat was coded to have symptoms regardless if those symptoms were known to be related to FIV-infection or not.

Fifteen different breeds were recorded for 1541 cats $(90 \%)$. European shorthair cats 
(i.e. domestic) and those without any information of the breed were coded as not purebred cats; all others were coded as purebreds.

The sex was recorded for 1507 cats $(87 \%$ of studied animals). Neutering status was recorded for 130 cats ( $8 \%$ of all data). Because the admission note did not have an alternative code for "not neutered", and because we had a suspicion that the proportion of neutered animals was not accurate, the information on neutering was not included in the analyses.

The age of the cat (available for 1288 cats; $75 \%$ ), was calculated from the time of birth to the time when the sample was drawn. Age was not normally distributed and was ana- lyzed both as a categorical variable ( 9 categories with 1-year intervals; the ninth category included all cats over 8 years of age) and as a continuous variable using a natural logarithmic transformation.

\section{Statistical analysis}

Statistical analyses were carried out using the Statistix (NH Analytical Software, 1989) and EGRET computer programs (1986). A twostage process was used to study the likelihood of a particular factor being associated with the risk of FIV. In the first stage, $2 \times 2$ and $2 \times \mathrm{n}$ chi-square tests were done to relate each potential determinant to FIV serology. If the assumptions for the chisquare test were not met, Fisher's exact test

Table 1. The distribution of anamnestic data of 804 and 909 cats submitted for FIV testing in 1990 and in 1991, respectively.

\begin{tabular}{|c|c|c|c|c|c|}
\hline \multirow[t]{2}{*}{ Characteristics } & \multicolumn{2}{|c|}{1990} & \multicolumn{2}{|c|}{1991} & \multirow[t]{2}{*}{$\mathbf{P}$} \\
\hline & No. & $\%$ & No. & $\%$ & \\
\hline \multicolumn{6}{|l|}{ FIV } \\
\hline Positive & 54 & 7 & 39 & 4 & \multirow{3}{*}{0.03} \\
\hline Negative & 750 & 93 & 870 & 96 & \\
\hline Total & 804 & 100 & 909 & 100 & \\
\hline \multicolumn{6}{|l|}{ Symptoms } \\
\hline Yes & 110 & 14 & 79 & 6 & \multirow{3}{*}{0.001} \\
\hline No & 694 & 86 & 830 & 91 & \\
\hline Total & 804 & 100 & 909 & 100 & \\
\hline \multicolumn{6}{|l|}{ Breed } \\
\hline Purebred & 395 & 49 & 509 & 56 & \multirow{3}{*}{0.004} \\
\hline Not purebred & 409 & 51 & 400 & 44 & \\
\hline Total & 804 & 100 & 909 & 100 & \\
\hline \multicolumn{6}{|l|}{ Sex } \\
\hline Male & 305 & 43 & 364 & 46 & \multirow{3}{*}{0.23} \\
\hline Female & 407 & 57 & 429 & 54 & \\
\hline Total & 712 & 100 & 793 & 100 & \\
\hline \multicolumn{6}{|l|}{ Age (years) } \\
\hline Mean & 3.4 & & 3.3 & & \multirow[t]{2}{*}{0.49} \\
\hline $\mathrm{Cl}_{95 \%}$ & $3.1-$ & & 3.0 & & \\
\hline
\end{tabular}


Table 2. Association between anamnestic data and ELISA test results of FeLV with FIV test results of 1713 cats submitted for testing during 1990 and 1991 in Finland.

\begin{tabular}{|c|c|c|c|c|c|c|}
\hline & \multicolumn{5}{|c|}{ FIV } & \multirow{3}{*}{$P$} \\
\hline & \multicolumn{2}{|c|}{ Positive } & \multicolumn{2}{|c|}{ Negative } & \multirow{2}{*}{$\begin{array}{c}\text { Missing } \\
\text { No. }\end{array}$} & \\
\hline & No. & $\%$ & No. & $\%$ & & \\
\hline FeLV & & & & & 0 & $0.42^{1}$ \\
\hline Positive & 3 & 9 & 30 & 91 & & \\
\hline Negative & 90 & 5 & 1590 & 95 & & \\
\hline Total & 93 & & 1620 & & & \\
\hline Symptoms & & & & & 0 & $<0.001$ \\
\hline Yes & 43 & 23 & 146 & 77 & & \\
\hline No & 50 & 3 & 1474 & 97 & & \\
\hline Total & 93 & & 1620 & & & \\
\hline Breed & & & & & 0 & $<0.001$ \\
\hline Purebred & 9 & 1 & 895 & 99 & & \\
\hline Not purebred & 84 & 10 & 725 & 90 & & \\
\hline Total & 93 & & 1620 & & & \\
\hline Sex & & & & & 207 & $<0.001$ \\
\hline Male & 68 & 10 & 603 & 90 & & \\
\hline Female & 20 & 2 & 815 & 98 & & \\
\hline Total & 88 & & 1418 & & & \\
\hline Age & & & & & 426 & $<0.001$ \\
\hline$<1$ & 3 & 1 & 270 & 99 & & \\
\hline $1-<2$ & 9 & 2 & 360 & 98 & & \\
\hline $2-<3$ & 0 & 0 & 183 & 100 & & \\
\hline $3-<4$ & 5 & 5 & 92 & 95 & & \\
\hline $4-<5$ & 4 & 5 & 79 & 95 & & \\
\hline $5-<6$ & 11 & 18 & 49 & 82 & & \\
\hline $6-<7$ & 4 & 11 & 34 & 89 & & \\
\hline $7-<8$ & 7 & 21 & 27 & 79 & & \\
\hline$\geq 8$ & 33 & 22 & 117 & 78 & & \\
\hline Total & 76 & & 1211 & & & \\
\hline
\end{tabular}

${ }^{1}$ Fischer's exact test

was performed. Student's t- test was used to relate continuous variables to serologic status.

In the second stage, the effect of single risk factors on FIV was examined further with multivariable logistic regression. The likelihood of a particular factor being associated with the risk of FIV was adjusted for other factors in the model. A backward stepwise approach was used to develop the final models (Kleinbaum et al. 1982). All main effects and all two-way interactions were included in the starting models. In the final models, only variables (or interactions) that were found to significantly affect the outcome were retained (except that if the interaction terms 
were significant, corresponding lower-order terms - whether significant or not - were included in the final models).

Because one of our concerns was that the motivation to submit samples for testing may have changed during the study period, 3 different data sets were analyzed: 1990, 1991, and both years, combined.

\section{Results}

The overall proportion of samples that were antibody-positive for FIV infection was $5 \%$. The number of tests performed increased slowly while the positive test results decreased over time. There were more symptomatic and domestic cats tested in 1990 than in 1991. No sex or age differences between the samples submitted in 1990 or 1991 were observed (Table 1).

In the whole data set, FIV antibodies were detected in 93 out of 1713 cats $(5 \%)$ and 33 had FeLV antigens (2\%) (Table 2). Three cats were also FIV-positive for FeLV antigen; however, there was not a statistically significant association between FIV and FeLV results $(\mathrm{P}=0.42$; Table 2$)$.

Only $11 \%$ of animals had information on symptoms. Positive test results among symptomatic cats were higher than among others
(Table 2). Domestic cats had a positive test result more often than so-called purebred cats (Table 2). Ten percent of studied males had FIV antibodies and $2 \%$ of females $(\mathrm{P}<0.01)$.

The median age for all cats was 2.0 years (range from 0.1 to 20.9). Information on age for FIV positive cats was available for 75 cats ( $80 \%$ of FIV-positive cats) and their median age was 7.0 years (range from 0.3 to 18.0). For FIV negative cats the information was available for 1211 cats (74\% of FIV-negative cats) and their median age was 1.9 years (range from 0.1 to 20.9). Age was not normally distributed; $50 \%$ of the animals were under 2 years old (Table 2). The frequencies of positive animals were statistically different; older animals had higher prevalence which increased in cats 5 years and older (Table 2).

Logistic regression models were developed for the data in the first, the second, and the first and second year combined. Because of similarity among the models, we present only that for both years, combined. The model included symptoms, breed, gender, the logarithm of age, and the interaction between sex and the logarithm of age (Table 3). The year was not a significant factor.

Table 3. Logistic regression model for Feline Immunodeficiency Virus ELISA test based on data from the 1225 cats with complete records submitted for testing in 1990 and 1991.

\begin{tabular}{lccccc}
\hline Variable & Coefficient & SE & P & OR & $95 \%$ CI \\
\hline Constant & -5.23 & 0.50 & $<0.001$ & & $2.3-7.1$ \\
Symptoms $^{1}$ & 1.40 & 0.29 & $<0.001$ & 4.1 & $2.2-13.5$ \\
Breed $^{2}$ & 1.71 & 0.46 & $<0.001$ & 5.5 & $0.2-2.1$ \\
Sex $^{3}$ & -0.38 & 0.57 & 0.51 & 0.7 & $0.9-2.4$ \\
Age (Ln) & 0.36 & 0.26 & 0.16 & 1.5 & $1.2-4.4$ \\
Sex $\times$ Age (Ln) & 0.83 & 0.33 & 0.013 & 2.3 & \\
\hline
\end{tabular}

1 Yes $=1 ;$ No $=0$

2 Not purebred $=1$; Purebred $=0$

${ }^{3}$ Male $=1 ;$ Female $=0$ 
The logistic regression technique allowed us to calculate the risk of FIV as a function of the determinants in the model. For example, a symptomatic, domestic male cat aged 5 years old had a $36 \%$ chance of being FIV positive (the model based on combined data, Table 3):

$$
P(\text { case })=\frac{1}{1+e^{-[-5.23+1.40(1)+1.71(1)-0.38(1)+0.36(\ln 5)+0.83(1 * \ln 5)]}}
$$

To demonstrate the interaction effect of age and sex we calculated the risk of FIV for male and female domestic cats with and without symptoms (Fig 1). The risk increased faster with age in males than in females (i.e., the age effect was not constant between sex). The cats with symptoms had always a higher risk than those without symptoms, but the effect of symptoms did not change as a function of age (i.e., the symptom/no symptom risk curves had similar slopes within sex).

\section{Discussion}

One major drawback of studies based on clinical data such as these is the difficulty in identifying the population at risk. Before one can generalize the results from this or any study, one has to consider the internal and external validity of the data set. Three major types of biases may affect the internal validity: selection, information, and measurement biases. Our data set was not a representative sample of the Finnish cat population. The

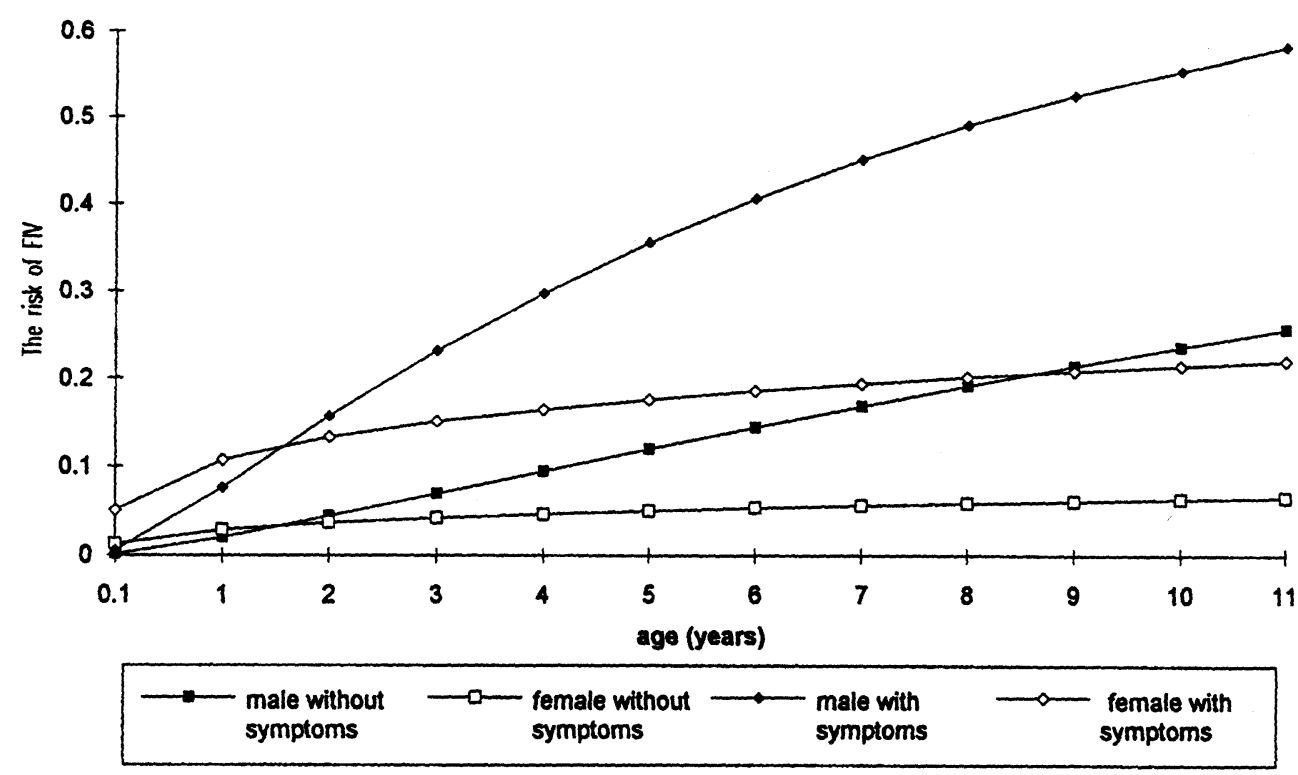

Figure 1. The risk of FIV for male and female domestic cats with and without symptoms. The risk calculation is based on the logistic regression model in Table 3. 
cats studied probably were different from the general cat population, because most cats do not receive veterinary care and would not have been tested. One may argue, however, that it is useful to study cats that receive veterinary care because this is the population of the cats with which veterinarians are most involved.

Another problem is introduced because the samples submitted were not chosen at random from cats brought to clinics. The probability of being selected for testing was not constant for all cats in Finland. This was especially true for purebred versus nonpurebred cats: There is no accurate information on the cat population in Finland, but one estimate is that there are from 400,000 to 450,000 cats in the country (Sairanen 1991) of which 20,000 are registered as purebred cats. In our material there were almost an equal number of purebred and domestic cats.

There was also misclassification bias in this study since the ELISA test is known to have a $2-20 \%$ false positive rate when used in veterinary clinics (Barr et al. 1991). Improper washing between steps in the assay leads to false positive results. The false positive rate in this study, however, is likely at the lower end of the range because all tests were run by experienced technicians in a central laboratory. Nevertheless, the Cite Combo test does misclassify some samples as positive even with proper technique. In this study 93 cats tested positive, but with a relatively rare disease and a moderately high false positive rate that reduces test specificity, the predictive value of a positive test result is low. This misclassification most likely leads to an underestimation of the effects of risk factors.

Although there are several well-known reasons why clinical material hardly ever is a representative sample of the cat population, we did not find a single study from the litera- ture which was carried out using a random sample from the general cat population ( $\mathrm{Neu}$ et al. 1989, Knowles et al. 1989, Friend et al. 1990, Hopper et al. 1989, Gruffydd-Jones et al. 1988, Hosie et al. 1989, Shelton et al. 1989, Yamamoto et al. 1989, Fleming et al. 1991, Lutz et al. 1990, Ishida et al. 1989, Grindem et al. 1989). To date, without general cat registries and limited economic resources for petanimal epidemiology, studies must use some type of convenience sampling.

Acknowledging the limitations associated with using these data, some of findings in this study are supported by biological realities. Certain behaviors of cats are believed to be associated with increased risk of infection. Our assumptions were that breed, sex, and age can be used as proxies of some aspects of the cat's behavior. Furthermore, the symptoms or a lack of symptoms may be used to provide information if the testing was initiated by a veterinarian to diagnose the disease or an owner to know if a non- symptomatic cat was FIV positive. Classifying cats either as purebred or domestic cats provided 2 different behavioral groups. Domestic cats were assumed to be more outdoor-indoor cats while the purebred cats were assumed to be more-exclusively indoor cats. To group cats having no breed information together with European shorthair cats, as outdoor cats, may have led to some misclassification (some indoor cats were included in this group) but perhaps introduced less misclassification than coding them with purebred cats (and including some outdoor cats as indoor cats). This misclassification in coding is assumed to underestimate the effect of free roaming and thus our conclusions tend to be conservative rather than overestimates of the risk of category "breed" for FIV infection.

Our results confirmed earlier findings that the cat's behavior is associated with the risk 
of FIV. Furthermore, we demonstrated that there was an interaction between age and sex. The biological basis for the increased risk is the assumption that FIV is spread among fighting cats by saliva through bite wounds. The interaction between sex and age may be explained by the fact that sexually mature male cats are more likely to be involved in fights and with time (=age and more fights), they are more likely to be exposed to FIV. A few positive results of very young kittens might be due to passive maternal antibodies.

Symptoms were considered to indicate if the testing was motivated by veterinary clinical reasons or by the owner's interest in monitoring their pet's health status. Because the presence of symptoms was associated with positive test results, one may speculate that even though there are not any specific symptoms for FIV, there are many features in clinical cases which alert the veterinarian to suspect FIV infection.

A change in the sampled populations was observed between 1990 and 1991. One explanation may be increased public awareness of FIV. Vetlab started FIV ELISA testing at the end of 1989. Because the disease was new, veterinarians were better informed initially and then awareness spread among cat owners. More symptomatic cats and more cats in high risk groups (domestic cats which are more likely to be free roaming than so called purebred cats) were tested in 1990. This suggests that the apparent decline in the percentage of cats found positive was not a real decrease of the prevalence in the target population but simply the reflection of change in sampling from the veterinarian's interest in diagnosing the disease in a symptomatic cat to the owner's interest in evaluating their apparently healthy cats for possible FIV infection. The change was proportional; veterinarians still continued to test cats suspected of infection, but owners started to request the test for animals at lower risk. Owners of purebred cats are often more enthusiastic about health care than are owners of domestic cats and thus are more willing to spend money on their pets. This was also seen in the proportion of the purebred cats in this study which was likely much higher than their representation in whole cat population.

Because of limitations in the clinical material and possible variation in the sampling in different geographical areas we did not estimate possible differences in the distribution of the diseases in Finland. A large study in the USA concerning symptomatic cats (O'Connor et al. 1991) did not show any regional differences. In Finland, cats are allowed to roam more freely in the countryside but are more dispersed than in urban areas where cat population density of outdoor cats is greater. Therefore, it would be interesting to determine if there are any differences in prevalence of antibodies in rural versus urban areas.

In conclusion, increased risk of FIV seropositivity was associated with cats that were not purebred, cats with symptoms at the time of the veterinary visit, and older male cats. Although these results agree with the literature and are biologically reasonable, a randomized study would provide stronger evidence that these associations are not attributable to sample and classification bias.

\section{References}

Anonymous: Epidemiologic, Graphics, Estimation and Testing Package (EGRET). Statistics and Epidemiologic Research Corporation, Seattle, Washington, 1986 a.

Anonumous: Statistix. Analytical Software, St. Paul, MN, 1989 b. 
Barr MC, Pough MB, Jacobson RH, Scott FW: Comparison and interpretation of diagnostic tests for feline immunodeficiency virus infection. J. Amer. vet. med. Ass. 1991, 199, 1377 1381.

Callanan JJ, Hosie MJ, Jarret O: Transmission of feline immunodeficiency virus from mother to kitten. Vet. Rec. 1991, 128, 332-333.

Connaughton D: What you need to know about the feline immunodeficiency virus. J. Amer. vet. med. Ass. 1989, 194, 169-173.

Fleming EJ, McCaw DL, Smith JA, Buening GM, Johnson C: Clinical, hematologic, and survival data from cats infected with feline immunodeficiency virus: 42 cases (1983-1988). J. Amer. vet. med. Ass. 1991, 199, 913- 916.

Friend SCE, Birch CJ, Lording PM, Marshall JA, Studdert $M J$ : Feline immunodeficiency virus: prevalence, disease associations and isolation. Aust. vet. J. 1990, 67, 237-243.

Grindem CB, Corbett WT, Ammerman BE, Tomkins MT: Seroepidemiologic survey of feline immunodeficiency virus infection in cats of Wake North Carolina. J. Amer. vet. med. Ass. 1989, 67, 226-228.

Gruffydd-Jones TJ, Hopper CD, Harbour DA, Lutz $H$ : Serological evidence of feline immunodeficiency virus infection in UK cats from 1975-76. Vet. Rec. 1988, 123, 569-570.

Hardy W: General principles of retrovirus immunodetection tests. J. Amer. vet. med. Ass. 1991, 199, 1282-1286.

Hopper CD, Sparkes AH, Gruffydd-Jones TJ, Crispin SM, Muir P, Harbour DA, Stokes CR: Clinical and laboratory findings in cats infected with feline immunodeficiency virus. Vet. Rec. 1989, 125, 341-346.

Hosie MJ, Robertson C, Jarrett O: Prevalence of feline leukaemia virus and antibodies to feline immunodeficiency virus in cats in the United Kingdom. Vet. Rec. 1989, 125, 293-297.

Ishida T, Washizu T, Toriyabe K, Motoyoshi S, Tomoda I, Pedersen NC: Feline immunodeficiency virus infection in cats of Japan. J. Amer. vet. med. Ass. 1989, 194, 221-225.

Kleinbaum D, Kupper L, Morgenstern H: Epidemiologic Research: Principles and quantitative methods. Van Nostrand Reinhold, New York 1982.

Knowles JO, Gaskell RM, Gaskell CJ, Harvey CE, $L u t z H$ : Prevalence of feline calicivirus, feline leukaemia virus and antibodies to FIV in cats with chronic stomatitis. Vet. Rec. 1989, 124, 336-338.

Kristensen ATS, Petersen SF, Hoff-Jorgensen, $R$ : Feline AIDS (FAIDS) og Feline Immunodiciency Virus (FIV). Dansk Vet Tidsskr. 1989, 72, 447-452.

Lutz H, Lehmann $R$, Winkler $G$, Kottwitz B, Dittmer A, Wolfensberger $C$, Arnold P: Das Feline Immunschwchevirus in der Schweiz: Klinik und Epidemiologie im Vergleich mit dem Leukmieund dem Coronavirus. Schweiz. (Feline immunodeficiency virus in Switzerland: clinical and epidemiological aspects in comparision with FeLV- and coronavirus infections). Arch. Tierheilk. 1990, 132, 217-225.

Neu H, Moennig V, Leidinger K, Bussian E: Erste Ergebnisse uber die Verbreitung FIV - (FTLV-) seropositiver Katzen in Deutschland und Interpretation der Ergebnisse. (First results of the distribution of FIV - (FTLV-) seropositive cats in Germany and interpretation of the results). Der praktische Tierarzt 1989, 3, 38-44.

North TW, North GLT, Pedersen NC: Feline Immunodeficiency Virus, a Model for Reverse Transcriptase-Targeted Chemotherapy for Acquired Immune Deficiency Syndrome. Antimicrob. Agents Chemother. 1989, 33, 915-919.

O'Connor TP, Tonelli QJ, Scarlett JM: Report of the National FeLV/FIV Awareness Project. J. Amer. vet. med. Ass. 1991, 199, 1348-1353.

Pedersen NC, Barlough JE: Clinical overview of feline immunodeficiency virus. J. Amer. vet. med. Ass. 1991, 199, 1298-1305.

Pedersen NC, Ho EW, Brown ML, Yamamoto JK: Isolation of a T-Lymphotropic Virus from Domestic Cats with an Immunodeficiency-Like Syndrome. Science 1987, 235, 790-793.

Povey RC, Hawkins GJ: Feline Immunodeficiency virus: a commentary. Can. vet. J. 1989, 30, 559562.

Sairanen J: Eläintenruokamarkkinat voimakkaassa kasvussa. (Animal food marketing strongly building up). Elintarvikeuutiset 1991, 13, 9-10.

Shelton GH, Waltier RM, Connor SC, Grant CK: Prevalence of Feline Immunodeficiency Virus and Feline Leukaemia Virus Infection in Pet Cats. J. Amer. Anim. Hosp. Ass. 1989, 25, 7-12.

Sukura A, Salminen T, Lindberg L-A: A Survey of FIV Antibodies and FeLV Antigens in Freeroaming Cats in the Capital Area of Finland. Acta vet. scand. 1992, 33, 9-14.

Yamamoto JK, Hansen H, Ho EW, Morishita TY, 
Okuda T, Sawa TR, Nakamura RM, Pedersen $N$ : Epidemiologic and clinical aspects of feline immunodeficiency virus infection in cats from the continental United States and Canada and possible mode of transmission. J. Amer. vet. med. Ass. 1989, 194, 213-220.

Yamamoto JK, Sparger E, Ho EW, Andersen PR, O'Connor T, Mandell CP, Lowenstine L, Munn $R$, Pedersen NC: Pathogenesis of experimentally induced feline immunodeficiency virus infection in cats. Amer. J. vet. Res. 1988, 49, 12461258.

\section{Sammandrag}

Samband mellan förekomst av antikroppar mot FIV och värdkarakteristika hos kattor $i$ Finland.

Finlands största veterinärkliniska laboratorium (Vetlab) som specialiserat sig på diagnostik av sällskapsdjur, har sedan slutet av år 1989 utför ett serologiskt test med ett kombinerat kommersiellt FIV -antikropps och FeLV antigen ELISA-test $\left(\right.$ Citecombo $\left.{ }^{R}\right)$. Vid en retrospektiv flervariabelanalys av dessa data som omfattar 22 månaders material, konstateras att FIV -ELISA test-resultaten är beroende av djurets ålder, kön, ras och hälsotillstånd. Dessutom konstaterades att ålder och kön tillsammans påverkar testresultatet. FIV och FeLV resultaten visade sig vara statistiskt oberoende av varann. Materialet visar att tyngdpunkten för intresset för testet håller på att förflytta sig från veterinärens diagnostik till djurägarens intresse för sällskapsdjurets hälsotillstånd. Denna trend har medfört att ett mindre antal FIV_utsatta undergrupper har deltagit testet och detta kommer möjligen $i$ längden att minska prevalensen av sjukdomsförekomsten i kliniskt material.

(Received June 15, 1992; accepted July 2, 1992).

Reprints may be requested from: A. Sukura, Department of Anatomy, College of Veterinary Medicine, P. O. Box. 6, SF-00581 Helsinki, Finland. 